\title{
A Unificação da Previdência Social
}

\author{
Dante de Souza Gondim \\ Técnico de Administração do I.N.P.S
}

(Bahia)

\section{REPERCUSSÃO NO SETOR FUNCIONAL}

LTIMAMENTE tem sido objeto de comentários em tôda a parte a unificação da previdência social. Raro é o dia ém que, na imprensa e meios de divulgação em geral, o público $e$ as classes interessadas em particular, através dos seus órgãos representativos, não fazem críticas, quase sempre desfavoráveis ao processo de fusão dos órgãos previdenciários.

O tipo de comentários que se formula revela, entretanto, ao mais das vêzes, uma completa desinformação em tôrno dos mais variados e até dos mais comezinhos aspectos do problema.

Mas, se isso não seria tanto de admirar, no que respeita ao grande público, já o mesmo não se poderia dizer em relação ao funcionalismo da previdência social, cuja desinformação sôbre a matéria seria muito menos justificável. Entretanto, o público interno da previdência social está tão pouco esclarecido a seu respeito, e por isso tão relutante em aceitar a unificação, quanto os que a criticam do lado de fora.

Com efeito, tivemos oportunidade de trocar idéias a respeito da unificação da previdência social com dezenas de funcionários de todos os órgãos previdenciários extintos. Podemos, por isso, afirmar que a quase totalidade dos servidores dos ex-Institutos estão declarada, frontal e mesmo hostilmente contra ela. O impacto do processo em tôdas as categorias funcionais e mesmo do comando administrativo foi, decididamente, negativo. $O$ pessoal não acredita no êxito da providência, que acha tumultuária e de efeitos contraproducentes. Poucas são as vozes expressamente 
otimistas e favoráveis à medida. São como que aves raras, clhadas por isso mesmo com surprêsa, curiosidade, quando não com indisfarçável suspeita.

Mas a reação não poderia ser outra. É que o funcionário foi como que considerado peça secundária no processo. Não afirmamos que isso tenha resultado de um propósito deliberado da administração previdenciária, pois algum trabalho, no particular do preparo do funcionalismo para a unificação, chegou a ser feito, pessoalmente, pelo ex-presidente do antigo IAPI e posteriormente diretor do DNPS, dr. José Dias Corrêa Sobrinho. $\mathrm{Na}$ Bahia, pelo menos, em palestra sôbre o assunto, procurou mobilizar o interêsse dos funcionários para as perspectivas positivas da fusão previdenciária. Mas o certo é que a falta de um procedimento sistematizado no particular, por parte da administração, encerra implicações de conteúdo negativíssimo, que os fatos estão a confirmar diàriamente, na presente conjuntura.

\section{ATITUDE DO PESSOAL NA DINAMICA DO TRABALHO}

Ora, a atitude do pessoal na dinâmica do trabalho em geral, é fator a ponderar-se devidamente, dentro da técnica da administração moderna. $O$ individuo, afinal de contas, encerra, do seu ponto-de-vista, a medida do valor e utilidade de tôdas as coisas e tudo o que existe e lhe diz particularmente respeito, só lhe importa enquanto lhe desperta motivações positivas. A compreensão dessa atitude natural do ser humano, por parte dos que lidam com as pessoas e particularmente dos que administram e comandam, revela um entendimento humanista do problema, mais consentâneo com as realidades psíco-sociais que condicionam o comportamento individual.

Entretanto, a, pelo menos aparente, subestimação da importância da atitude do funcionário no caso específico da unificação da previdência social, como que lançou os seus gestores entre os que seriam indiferentes a essas peculiaridades do comportamento humano. $\mathrm{O}$ indivíduo e sua problemática não importaria tanto aos imbuídos dessa filosofia administrativa utilitária. O que contaria, antes de tudo, seria o alcance dos objetivos da organização. Mas aí é que êles se deparam com um paradoxo desconcertante. Com efeito, se, para atingir os fins visados, tem-se que recorrer, inelutàvelmente, ao individuo, como instrumento natural de trabalho e realizações, como desconhecer-lhe os condicionamentos e fazer tabula rasa de suas limitações, sem sacrifício dêsses mesmos fins?

As conseqüências prováveis dessa omissão no planejamento da unificação, poder-se-iam patentear numa série de comportamentos funcionais negativos, resultantes da queda do.moral dos grupos e da perda das motivações indispensáveis a um comporta- 
mento funcional construtivo. Isso manifestar-se-ia usualmente, em entraves deliberados ao processo de trabalho, suscitados por caracteres mais agressivos; em manifestações de desinterêsse e resistências dissimuladas, praticadas por personalidades menos afeitas às lutas abertas, mas tudo sempre com prejuizo da eficiência do trabalho. Ensejaria, ainda, essa conjuntura desfavorável, clima propício à ação comprometedora de elementos portadores de escasso senso ético, sempre à espreita para ações eivadas de oportunismo. Cabe, também, mencionar como fator de comprometimento global do êxito do programa, o afastamento, principalmente pela aposentadoria, de descoroçoados servidores veteranos, cuja experiência se perderia, assim, numa hora crítica, nessa fuga generalizada para a inatividade ou para outros setores ocupacionais.

Êsse quadro negativo não deixaria logo de atingir o ambiente externo da organização e no caso especial do serviço público, seria particularmente danoso, tendo em vista que o seu custeio é um encargo que onera a economia de todos e por isso a todos preocupa e afeta, de modo decisivo. Sim, porque um funcionalismo desinformado e descontente é, necessàriamente, veículo de falsos argumentos e meias verdades, quando não de deliberadas distorções, que se filtram para o público, com todo o cortejo de repercussões prejudiciais ao conceito da organização e de sua política administrativa. E isso é tanto mais sério quando se considera que o funcionário é, de modo geral, considerado portavoz muito autêntico, em relação às ocorrências que dizem respeito à entidade a que serve. Ora, não há administração que possa resistir, demoradamente, ao impacto de uma opinião pública desfavorável, trabalhada pelo preconceito e pela detração.

\section{CAUSAS NATURAIS DO DESCONTENTAMENTO FUNCIONAL}

Entretanto existem razões naturais para o descontentamento funcional. Cumpre considerar primeiro, e principalmente, a quebra e dispersão dos grupos funcionais, que a unificação tem provocado e continuará a provocar. A constelação de grupos sociais em que circula e se integra o indivíduo, é, sabidamente, de suma importância no condicionamento do seu modo de ser e de agir. A moldagem da personalidade é inclûsive feita, principalmente. nessas coletividades, que vão da família, primeiro núcleo natural em que nasce e cresce o indivíduo, até o grupo profissional e de trabalho onde, normalmente, se completa social e psiquicamente.

As amizades resultantes da convivência, as interações habituais das pessoas, explicam a dinâmica e coesão dêsses grupamentos, que não se rompem com facilidade e sem trauma. As cliques e «igrejinhas» sobretudo, têm raizes mais fundas no 
campo dos interêsses individuais e não podem, por isso, também, ser demolidas sem resistências.

Dir-se-á que haverá sempre possibilidades de formação de novos grupamentos. Felizmente, isso é verdade. Mas essa expectativa, conquanto natural, não pode concretizar-se sùbitamente. É que ela não é tão simples como poderia parecer à primeira vista, devido às naturais reservas com que mùtuamente se acolhem, de modo geral, os estranhos. Hospes, hostes - o estranho é inimigo - diz o aforisma no seu exagêro e na sua sintese severa, explicando essas desconfianças latentes. E a carga de preconceitos e estereótipos que cada um traz, traduzida, muitas vêzes, em curiosos sentimentos de superioridade e inferioridade, em ojerizas, em indisposições e idiosincrasias várias, não deixa de aumentar as dificuldades de integração perfeita das pessoas em novas coletividades. E, no caso, não deixariam de influir negativamente, também, as naturais emulações resultantes da busca das posições e melhorias do «status» funcional, na nova entidade previdenciária unificada.

Outro elemento a ser considerado como fator de descontentamento funcional é o que diz respeito, mais especificamente, às alterações das rotinas de trabalho. De repente, tôda uma mecânica de processos, métodos, fórmulas e sistemas burocráticos, foram modificados, supressos, adaptados. Hábitos arraigados de procedimento funcional são repentinamente substituidos por outros. Isso representa uma verdadeira convulsão mental, pois a ojeriza ao nôvo, o apêgo ao tradicional, é a marca do comum das pessoas. Elas se deleitam, numa atitude psicológica perfeitamente compreensivel, com a repetição pura e simples do que não incomoda, pois só o que traumatiza e cansa é capaz de desencadear um processo de modificação de comportamentos. Daí a relutância em mudar, ainda que com objetivos comprovados de melhoria. Some-se a isso a carga de sentimentalismo que muitos projetam nas coisas, pessoas, ambientes e situações - como o caso daquela funcionária que chorou ao ver a plaqueta do seu guichê retirada - e ter-se-á idéia mais nítida do que representa a rotina da vida na existência da maioria. Só os imbuídos de espírito construtivo e renovador, se empenham e se comprazem em alterar a mesmice da existência, imprimindo às coisas a dinâmica do progresso. Ainda bem que êles existem, pois os avanços da humanidade e da civilização são fruto do seu inconformismo e inquietação. Não fôssem êles e estaríamos, ainda, nos estágios mais rudimentares da cultura.

Acresce, ainda, que o receio de perda de vantagens e situações funcionais preexistentes, preocupa, particularmente, os que exercem encargos de chefia, em todos os escalões da hierarquia administrativa, pois um dos efeitos naturais da unificação seria a estruturação da novel entidade previdenciária, numa verdadeira 
unidade organizacional, ou não seriam alcançados os objetivos fundamentais da fusão. Ora, essa nova estrutura haveria de, necessàriamente, provocar modificações na localização e delimitação das esferas de comando e supervisão. Não mais do que isso, acreditamos, pois que, considerado o campo de ação útil de comando, ditado pela experiência e representado pela relação de 1 chefe para cada 7 subordinados, haveria, com certeza, lugar para todos os atuais titulares de chefias, no INPS.

\section{II}

\section{AS CRITICAS AO INPS}

As críticas ao INPS e suas potencialidades, formuladas no âmbito interno e externo, e neste último mais por influência do que se comenta internamente a respeito, abrangem uma gama variadissima de aspectos da previdência, que vão desde os estritamente técnicos e administrativos, até os de caráter mais nitidamente social e político. E em tôdas essas críticas vislumbra-se uma desinformação patente, quando não o preconceito manifesto.

\section{O FORTALECIMENTO TECNICO-ATUARIAL DA PREVIDENCIA}

Desconhecem, por exemplo, os opositores da unificação que a reunião da previdência social brasileira no Instituto Nacional de Previdência Social (INPS), era um imperativo de ordem econômica e administrativa inelutável. Sobretudo, motivos de ordem técnico-atuarial a impunham.

Sendo a atuária uma ciência, a técnica dos seguros, de que é instrumento necessário, não pode deixar de impor diretrizes científicas à correta administração dos órgãos seguradores. seguro, seja êle privado ou social, voluntário ou obrigatório, lida com c que, na terminologia específica, se chama, não muito adequadamente, aliás, de sinistros e que não são senão os riscos, ou eventos potenciais cobertos pelo sistema, já ocorridos ou realizados. Êsses fenômenos, conquanto singularmente imprevisíveis, nem por isso prescindem da lei dos grandes números ou da sua observação em massa, para determinação da sua frequiência e formas de apresentação estatística. Requer, portanto, a técnica securitária, grandes coletividades seguradas para ensejar estudos tão exatos quanto possiveis no que respeita à previsão dos sinistros e obtenção dos recursos financeiros necessârios à cobertura dos encargos dêles decorrentes.

No caso específico do seguro social brasileiro, o seu fracionamento, em seis entidades seguradoras, representava fator de enfraquecimento econômico de algumas delas, devido à pequena 
massa de segurados que, em alguns casos, apresentavam. Ora, - INPS, reunindo tôdas as categorias profissionais numa única massa segurada tem, por isso mesmo, uma maior capacidade de resistência técnica e financeira, do que cada uma das entidades que absorveu.

\section{O PROBLEMA DO CUSTO OPERACIONAL}

Os custos operacionais, por outro lado, são, inelutável e proporcionalmente, sempre mais altos em entidades seguradoras pequenas, pois qualquer máquina administrativa, por menor que seja, requer tôdas as complexidades das similares grandes, principalmente se tiver que seguir um padrão organizacional estabelecido em lei. Não há prodígio de organização e eficiência que consiga evitar isso.

Há, com efeito, uma proporcionalidade inversa entre a massa segurada compreendida no âmbito de ação do órgão segurador e os seus custos operacionais. Quanto menor essa massa, maior, proporcionalmente, as suas despesas administrativas. Tome-se, por exemplo, a razão funcionário-segurado, que dá uma boa idéia da mais ponderável rubrica de custeio administrativo, isto é, a de pessoal, e ter-se-á uma visão nítida do problema. Assim, cotejando-se a relação funcionário-segurado, prevalecente na que foi a maior instituição de seguro social do País, anteriormente à unificação, isto é, o antigo IAPI, com a mesma relação existente na menor de tôdas, o ex-IAPM, verifica-se que, enquanto o ex-IAPI mantinha um servidor para cada 109 segurados, o antigo IAPM apresentava um funcionário para cada 16 contribuintes. Isso significa que as despesas de pessoal do ex-IAPM, admitindo-se um custo funcional médio, idêntico, nos dois órgãos, seriam proporcionalmente, quase sete vêzes superiores às do ex-IAPI. Não se diga que o ex-IAPM teria sido prêsa, em particular, do empreguismo e do esbanjamento de recursos, porque a verdade é que, a despeito de todos os percalços, consideradas as deficiências econômicas, culturais e sobretudo as práticas políticas do País, as Instituições de Previdência eram, tôdas, de modo geral, satisfatoriamente administradas.

Embora a Lei Orgânica da Previdência Social previsse limites de sobrecarga administrativa para as despesas de administração dos antigos IAP, o quadro de custos operacionais absorventes que os mesmos apresentavam não pôde, até hoje, ser obviado.

É natural, entretanto, que se espere, em relação à novel Entidade previdenciária única, que ela acarrete melhoria da eficiência administrativa e correlata baixa do custo operacional da previdência social brasileira. Isso resultará, necessàriamente, de um correto aproveitamento dos efetivos funcionais unificados, anteriormente disseminados em meia dúzia de órgãos empenha- 
dos na realização sextuplicada de atividades da mesma natureza, bem como da padronização e simplificação das rotinas e da racional utilização de seu material, instalações e recursos financeiros. As primeiras providências para implantação do INPS já deixam antever claramente isso, ainda para os mais cépticos e descrentes, pois as sobras de pessoal são patentemente visiveis nos setores já unificados.

\section{PLANOS INTEGRADOS}

Uma análise sumária da ação administrativa das extintas entidades, levaria, por outro lado, os opositores da unificação, a conclusões francamente desfavoráveis às programações de atividades daquelas. Os antigos Institutos se empenhavam, com efeito, por fôrça de sua autonomia legal, em planos que compreendiam atividades fragmentárias, num patente desperdício de recursos e esforços. Daí resultavam, não raro, serviços pouco eficientes, decorrentes, principalmente, da insuficiência de recursos disponíveis, isoladamente, pelos IAP, para fazer algo realmente completo e satisfatório.

No campo da assistência médica isso era particularmente notório. Em alguns lugares, muitas das extintas entidades mantinham serviços médicos paralelos e deficientes, quando a reunião dos seus recursos poderia conduzi-los a programações comunitárias mais produtivas.

A possibilidade de planos únicos, com aproveitamento global dos recursos da previdência e cobrindo integradamente, todo o campo de suas atividades, resulta, por outro lado, noutra, e mais promissora perspectiva da novel Entidade.

\section{CENTRALIZAÇÃO E DESCENTRALIZAÇ̃OO. PRINCÍPIOS ESTABELECIDOS PELA REFORMA ADMINISTRATIVA}

Nem se diga, como já tem acontecido, que o INPS, por ser, talvez, a maior entidade da administração pública indireta do Pais, se tornaria, por isso mesmo, num pesado mamute administrativo, supercentralizado e de lentos movimentos. Êsse é, apenas, um dos muitos equívocos da opinião leiga sôbre o assunto. Unificação e centralização não são características necessàriamente correlatas. Órgãos pequenos podem ser excessivamente centralizados e emperrados na sua mecânica e desempenho, enquanto que grandes máquinas são raro são modelos de descentralização e flexibilidade administrativas. Alguns exemplos podem dar idéia nítida do problema. Assim, a fôlha de pagamentos do pessoal do antigo Instituto dos Bancários na Bahia, ainda há pouco era feita no Rio de Janeiro (!). Isso pode ser considerado o máximo 
de centralização em relação a um interêsse estritamente local e que poderia ser localmente muito bem cuidado e resolvido, para maior satisfação, inclusive, dos servidores do ex-IAPB, lotados na Bahia. Já o ex-IAPI, que era uma das maiores máquinas administrativas do País, despachava, sistemàticamente, processos de benefício nos níveis de execução. Essa entidade era, assim, um exemplo salutar de descentralização administrativa e num dos setores fundamentais de suas atribuições legais.

Escassa delegação de competência e descentralização de atividades eram, podemos afirmar, uma das características dominantes da previdência social fracionada, apesar de exceções apontáveis. E os seus efeitos junto à clientela eram, de modo geral, sabidamente negativos. Processos que poderiam ser normalmente resolvidos, sem quaisquer prejuízos, em órgãos periféricos e nos niveis de apresentação dos requerimentos, seguiam uma verdadeira Via crucis de passos, variados e supérfluos, subindo e descendo a escala da hierarquia administrativa. Tempo precioso perdia-se nesse percurso, não raro com penoso sacrifício das partes.

Os princípios da delegação e descentralização parece que se incorporaram definitivamente, como fundamentos básicos, às nossas práticas administrativas. A recente Lei da Reforma Administrativa preceitua-o formalmente, ao estabelecer que as atividades da administração federal serão amplamente descentralizadas. Estipula êsse diploma legal que a «administração casuística, assim entendida a decisão de casos individuais, compete, em princípio, ao nível de execução, especialmente aos serviços de natureza local, que estão em contacto como os fatos e com o público» ( $\S 3^{\circ}$, do artigo 10 , do Decreto-lei $n^{\circ} 200$, de 25 de fevereiro de 1967). Reitera-o, ainda, no artigo 11, ao estabelecer que a «delegação de competência será utilizada como instrumento de descentralização administrativa, com o objetivo de assegurar maior rapidez e objetividade às decisões, situando-as na proximidade dos fatos, pessoas ou problemas a atender». Essa, alias, a lição de Taylor, vivenciada, principalmente, nas atividades privadas, sempre mais premidas pela necessidade de poupar recursos, ganhando tempo.

Os órgãos de cúpula e comando, dentro dessa filosofia administrativa, ficariam adstritos às funções que the são inerentes. Isto é, ao planejamento, à supervisão, à coordenação e contrôle, ficando «liberados de rotinas de execução e de tarefas de mera formalização dos atos administrativos». Quanto à atividade de contrôle, que constitui uma verdadeira obsessão de certa categoria de administradores menos avisados, determina a aludida lei que devem ser simplificados e mesmo supressos, sempre que sejam puramente formais ou de custo superior aos prejuizos e falhas que procuram evitar. 
Vê-se, assim, que a Lei de Reforma Administrativa, formula regras de ação verdadeiramente revolucionárias, que sacudirão, certamente, se convenientemente aplicadas, a velha máquina de nossa administração pública, adaptando-lhe o ritmo de funcionamento à dinâmica desta era tecnológica, a que nos havemos, aliás, decididamente incorporados, pelo esfôrço de industrialização em que estamos empenhados, para nos incluirmos na grei das nações desenvolvidas.

Desde que se impregne da filosofia gerencial adotada pela Lei de Reforma Administrativa, não vemos por que não augurar ao Instituto Nacional de Previdência Social o êxito que tem tôdas as possibilidades de alcançar e a curto prazo. Pensar o contrário, à base de argumentos inconsistentes e razões especiosas, equivale a aferrar-se o pessimista a preconceitos e ao saudosismo de situações superadas, por incompativeis com os ideais de progresso e desenvolvimento.

\section{OUTRO EQUIVOCO DA OPINIIO LEIGA. OS FINS \\ DA PREVIDENCIA SOCIAL}

Apresentam, ainda, alguns, como fator contra-indicante da unificação, peculiaridades da problemática securitária de algumas categorias profissionais que constituiam a massa segurada específica das extintas entidades.

Acham, por exemplo, que determinados grupos profissionais, menos precisados de recorrer ao seguro social, passariam a custear por isso mesmo os encargos resultantes dos que mais solicitassem os serviços do sistema. Isso é verdade, porque essa é, aliás, a filosofia da previdência social. Longe de ser um mal, portanto, é uma de suas decorrências mais naturais e desejadas. Por essa forma, alcança-se, inclusive, um dos seus objetivos fundamentais, isto é, a redistribuição a um tempo geográfica e social da renda nacional. Os que podem mais, pagam para os que podem menos e das regióes ricas fluem os recursos para cobrir os encargos sociais emergentes nas regiões pobres, de baixa arrecadação. Representa, portanto, o-seguro social, por êsse prisma, um fator importante de reequilibrio social e de manutenção da capacidade econômica da parte da população atingida por eventos que lhe afetam o poder de consumo. Ora, o INPS é um instrumento mais adequado e potencialmente mais eficiente para o alcance dêsse objetivo, visto como os seus recursos constituem uma universalidade a ser utilizada de acôrdo com programações globais. 


\section{O INPS UM ESTADO DENTRO DO ESTADO? UMA AFIRMATIVA RETORICA}

O INPS seria, talvez, hoje, a maior e mais poderosa entidade pública do País, depois da pessoa do próprio govêrno federal, pois engloba no seu âmbito jurisdicional, 6 milhões de segurados, 12 milhões de dependentes, num total de 18 milhões de beneficiários, cujos interêsses seriam atendidos por $90 \mathrm{mil}$ funcionários. O seu orçamento, que atinge a cifra de 3,5 trilhões de cruzeiros velhos, viria logo em seguida ao da União.

Muitos vêem nisso um mal, pois entidades demasiado poderosas pelo vulto de suas disponibilidades financeiras, constituir-seiam, no final de contas, em verdadeiro Estado dentro do Estado. E que haveria o risco de êsses recursos serem utilizados como instrumento de alcance de interêsses outros que não os previstos na legislação própria. Como mecanismo de ação e pressão política, essa máquina gigantesca seria, pois, particularmente perigesa.

Esses são, entretanto, exageros, com escassa comprovação prática, mesmo entre nós, que ainda somos uma democracia incipientemente estruturada.

A demissibilidade «ad nutum» de sua administração; a fiscalização e contrôle jurisdicional exercidos pelas categorias profissionais e econômicas interessadas através do Conselho Fiscal e das Juntas de Recursos da Previdência Social - um e outras de composição paritária; a vigilância exercida pela administração federal através do Departamento Nacional da Previdência Social, do Serviço Atuarial, do Conselho de Recursos da Previdência Social e do Tribunal de Contas, para não mencionar a fiscalizaşão genérica mantida por tôda a coletividade nacional que, cada vez mais, se politiza e toma consciência dos problemas que lhe afetam os interêsses, mais diretamente - tudo isso haveria de minimizar a ação eventualmente prepotente e prejudicial de administrações menos cônscias dos seus verdadeiros encargos e responsabilidades.

Acolher-se, pois, êsse argumento, seria, apenas, negar ao Estado a sua caracteristica mais fundamental, isto é, a de poder superior e incontrastável dentro da comunidade política, o que redundaria, em última análise, na negação mesma da ordem jurídica.

Não passa, portanto, a afirmativa de que o INPS seria um Estado dentro do Estado, de uma frase de conteúdo meramente retórico.

\section{ADMINISTRAÇAO COLEGIADA E SINGULAR}

A lei que criou o INPS retomou o critério do comando singular para a previdência social, repudiando a forma colegiada dos Conselhos Administrativos previstos pela Lei Orgânica da 
Previdência Social para a direção executiva das extintas entidades. Substituiu-os, na novel Entidade por um presidente de livre nomeação do Presidente da República. Muitos consideram isso um retrocesso, pois entendem a administração colegiada, sobretudo, uma conquista das categorias econômicas e profissionais interessadas no seguro social, visto como participavam, por intermédio de seus representantes nos citados Conselhos, da direção de seus órgãos executivos.

Entretanto, o principio da unidade de comando continua a ser uma regra prática básica de administração. Em tôda a parte onde o executivo assumiu a forma colegiada, o rendimento administrativo foi sempre inferior às expectativas mais modestas. Adota-se, com proveito, o colegiado em órgãos consultivos ou de mero contrôle administrativo e jurisdicional. Essa, a lição vivida na experiência diuturna dos mais variados tipos de organização em tôda a parte.

Nem estariam as classes interessadas ausentes da mecânica administrativa do INPS, pois continuam a participar da composição do seu Conselho Fiscal e de suas Juntas de Recursos, de uma forma paritária, como nas estruturas fragmentárias extintas.

\section{O EXEMPLO DO SETOR PRIVADO}

A fusão de emprêsas no setor privado, mesmo entre nós, que ainda estamos na infância de um capitalismo pròpriamente dito, tem sido prática diuturna. Sobretudo a necessidade de manter custos operacionais baixos, para que possam enfrentar as rudezas de uma economia cada vez mais competitiva, tem comąndado essa diretriz no mundo dos negócios particulares. $E$ isso sem comprometimento da dinâmica de um mercado livre, para desencanto dos que rezam pelo catecismo marxista, que vêem no processo, apenas, uma marcha inexorável para o monopólio econômico em proveito de um número cada vez menor de privilegiados.

Mas a verdade é que a concentração de emprêsas em unidades maiores tem assegurado a manutenção do nivel de emprêgo, pois garante a continuidade de entidades que apresentem debilidades econômicas, conservando, assim, ocupada a mão-de-obra; tem concorrido para a melhoria dos niveis de preços de bens e serviços, pois possibilita a manutenção dos seus custos em limites compativeis com a capacidade de consumo e, finalmente, tem assegurado a indispensável remuneração dos investimentos, fulcro e razão de ser da economia capitalista.

Infelizmente, porém, o exemplo das fusões e incorporações no setor privado, pouca impressão causa a certa categoria de administradores públicos. Êles acham que o serviço público não precisa se preocupar tanto com o problema dos custos operacio- 
nais, porque, via de regra, não têm objetivos econômicos, como sói acontecer, normalmente, com a atividade privada. Atender ao público, seja a que preço fôr, seria o alvo principal da atividade estatal.

Essa é, entretanto, uma visão primária e sobretudo inconseqüente da questão. Os que a perfilham não atentam para as profundezas do problema e muito menos lhe alcançam os efeitos danosos.

$\mathrm{Na}$ verdade, se os serviços públicos são custeados por tributos que afetam a economia de todos, pois que todos os pagam, há, obviamente, influência da atividade estatal na economia do País. Essa influência é tão decisiva que, se o custeio dos serviços públicos fôr demasiado absorvente dos recursos coletivos, poderá ocasionar estagnação ou mesmo uma recessão na economia nacional. Serviços públicos que, portanto, operam a custos demasiado onerosos para o contribuinte, equivalem a um verdadeiro processo de autofagia na Nação.

Cumpre, pois, trazer o mesmo espírito gerencial da emprêsa privada para o serviço público. Há de haver, portanto, da parte dos lideres da administração pública, um propósito permanente de racionalizar as estruturas organizacionais, de simplificar métodos de trabalho, de modernizar enfim os serviços estatais, aproveitando-lhes, principalmente, da maneira mais eficiente possivel, os recursos materiais e financeiros e, principalmente, os seus efetivos funcionais. Isso porque, se a ineficiência e o desperdício, no setor privado, são punidos com a falência, no serviço público essa mesma condição resultaria noutro tipo de insolvência, de efeitos não menos danosos para a coletividade e que se traduziria no empobrecimento, sem contraprestação equivalente, dos contribuintes. Ora, um govêrno que empobrece o seu povo perdulàriamente, empobrece e enfraquece a si mesmo.

Não se pode censurar, portanto, ao atual govêrno, quando, imbuído de uma sadia política gerencial, haurida, também, nos exemplos da atividade privada, promoveu a unificação da previdência social brasileira, num órgão potencialmente muito melhor capacitado para alcançar os objetivos sociais do sistema previdenciário.

\section{O EXEMPLO ESTRANGEIRO}

Para os que usam o argumento da existência de exemplos estrangeiros de previdência social administrada fragmentàriamente, à moda da nossa, anterior ao INPS - argumento êsse que nada prova por si mesmo, de vez que êsse mesmo sistema de administração pode, alhures, apresentar os mesmos defeitos que apresentava entre nós e ser, por isso, tão condenável no estrangeiro quanto o era aqui - a êsse argumento podemos opor 
o de numerosos grandes países que gerem o seu seguro social de uma forma unificada.

Com efeito, as grandes nações industriais do mundo, com seus amplos planos de seguro social, que abrangem, em muitos casos, tôda a população ativa, administram-nos, unificadamente. Citemos por exemplo a Inglaterra, que o faz através do Ministério do Seguro Nacional (Ministry of National Insurance), enquanto que nos Estados Unidos, a Administração do Seguro Social (Social Security Administration) gere, também, unificadamente, o seguro social americano, para uma massa de mais de sessenta milhões de segurados.

Ora, quando essas nações líderes do mundo, que têm realmente uma experiência maciça de problemas administrativos de tôda a sorte, optaram por êsse sistema, não foram certamente levadas por uma preferência imotivada, mas pela necessidade imperiosa de obter um bom rendimento do órgão executivo, visando a que atinja os seus objetivos com eficiência e, sobretudo. com economia.

\section{IDENTIDADES BASICAS ENTRE O INPS E OS EX-IAP}

Nem foram tão profundas, assim, as modificações sofridas pela previdência social brasileira com a novel entidade previdenciária. Houve, apenas, bàsicamente, uma absorção das personalidades jurídicas das extintas entidades, com o objetivo de sua integração administrativa numa unidade organizacional superveniente, o INPS.

A forma de administração autárquica, com ampla autonomia administrativa e financeira do órgão executivo, foi mantida. Os planos de benefícios e a forma do seu custeio são os mesmos previstos na Lei Orgânica da Previdência Social e no seu recente Regulamento, aprovado pelo Decreto $60.501 / 67$. A participação das categorias interessadas nos órgãos de contrôle jurisdicional e administrativo internos e ministeriais, foi também respeitada.

Procurou-se, evidentemente, dar ao INPS uma estruturação mais compativel com os seus encargos que são enormes, de modo a que possa cumprí-los com presteza e economia. Delegação e descentralização, coordenação e contrôle racional são principios que devem, por isso, permear a sua filosofia administrativa, dando-se ênfase à concentração de tarefas executivas em órgãos periféricos. Aí, precisamente, reside a maior fonte de êxito do INPS.

Se falharem nesse propósito, os administradores do INPS terão apenas substituido sete entidades pouco eficientes, por ıma única, dificilmente melhor do que elas. 


\section{FALHARA, O INPS, EM SEUS OBJETIVOS ESPECÍFICOS? AS DEFICIENCIAS DA PREVIDENCIA SOCIAL}

As Cassandras da burocracia negativista auguram, inclusive, - fracasso do INPS, no que respeita ao alcance dos seus objetivos específicos. Entretanto, se a novel Entidade, como ocorria já com as antigas, não alcançar as metas legais do seguro social, com a plenitude que todos esperamos, isso não será, sempre, necessàriamente, uma falha de sua dinâmica administrativa. Em todo o caso, o INPS nunca será, disso temos a certeza, menos eficiente ou mais dispendioso do que qualquer dos órgãos que absorveu.

Aliás, podemos afirmar, com sobra de razões, que as possíveis falhas do INPS, que certamente as terá como quaisquer organizações humanas em qualquer parte - não serão sempre imputáveis, de plano e em todos os casos, à sua forma de operação do sistema previdenciário. Essas deficiências serão, é quase certo, atribuiveis, no que respeita ao cumprimento dos seus encargos específicos, principalmente, às carências sociais e sobretudo econômicas, do País.

Com efeito, um Pais que tem apenas 30 mil médicos e que necessita de, pelo menos, 90 mil, para atender a sua população em condições mínimas de eficiência, não pode, evidentemente, prestar, por exemplo, uma assistência médica previdenciária, sequer sofrivel, aos seus beneficiários, em tôda a extensão do território nacional. A $50 \%$ dos municipios brasileiros não poderia, mesmo, ser levada a mais elementar forma de assistência médica, pois ascende a cêrca de duas mil as comunas que não possuem sequer um médico residente nos seus limites geográficos.

O quadro econômico geral, por outro lado, ainda não assegura possibilidades de um total cumprimento de planos assistenciais previdenciários, devido ao seu custo necessàriamente alto. A nossa economia continua sendo, com efeito, dominantemente agrária, como o atesta a concentração maciça de mão-de-obra no setor primário ou agropastoril, onde moureja, em condições de elementar produtividade, em níveis, ao mais das vêzes, de mera subsistência, uma mão-de-obra que alcança o coeficiente de 17 milhões de trabalhadores. Êsse quadro econômico que apresentamos, a despeito do esfôrço de industrialização e patente progresso verificado em algumas áreas, é o exemplo clássico das economias primárias e subdesenvolvidas. Nelas, a ação governamental dificilmente vai além das áreas urbanas e a capacidade de desembôlso do contingente populacional ativo, para o custeio das despesas públicas e dos encargos assistenciais, é limitada àqueles grupos já incorporados à economia monetária de maneira decisiva, ficando os demais à margem dos benefícios da civilização e do progresso, por não poderem concorrer para o seu custeio de maneira substancial. 
Assim, o êxito de qualquer plano de alcance social, depende bàsicamente, do realismo e objetividade com que foi formulado, em função dêsse condicionamento econômico. E o nosso sistema previdenciário não haveria de ser exceção a essa regra. Se, portanto, muita coisa que foi prometida à massa segurada não tem sido alcançada na medida sequer do razoável - a despeito do esfôrço que se tem feito para cumprir a lei - é que, entre almejar ideais de justiça e a possibilidade de alcançá-los, com êxito, vai, na prática, uma distância não raro muito grande.

Mas, apesar disso, cumpre afirmar que a previdência social brasileira, a despeito de tôdas as suas deficiências, já é uma irrecusável realidade jurídica e social, como o atesta o interêsse manifesto por todos os grupos econômicos em contribuir para a mesma. E o INPS tem, comprovadamente, maiores possibilidades de suprir-lhes as falhas, à medida do progresso sócioeconômico do País, do que as entidades fragmentárias extintas.

\section{ANTECEDENTES HISTÓRICOS DA UNIFICAÇAO}

Mas a necessidade de robustecer atuarial e administrativamente o seguro social brasileiro, já vinha determinando a fusão paulatina dos seus órgãos. O que ocorreu com as antigas Caixas, instituidas por emprêsas ou de âmbito estritamente regional, na fase incipiente de nossa previdência, é um exemplo disso. Delas, chegou a haver mais de cem, que foram sucessivamente integradas em unidades maiores, até que, em 1953, cêrca de trinta remanescentes tiveram de ser fundidas num órgão único, a CAPEESP, depois denominada IAPFESP.

Já se vê, portanto, que o processo de fusão da previdência social brasileira está longe de ser, como acreditavam alguns, uma novidade. Todos os funcionários do ex-IAPFESP já viveram a experiência e os do IAPETC também, quando absorveu, essa entidade, em 1945, o Instituto da Estiva.

E a previsão de um Instituto único também não é nova, pois chegou a ser objeto de ato promulgado em 1945, a Lei dos Serviços Sociais, que criava o Instituto de Serviços Sociais do Brasil. As modificações politicas da época impediram, entretanto, que essa entidade chegasse a se tornar uma realidade.

Vem, por conseguinte, com atraso de vinte e dois anos em relação à programação inicial, o atual Instituto Nacional de Previdência Social. A identidade de fins dos órgãos da previdência social, a unidade de sua legislação e os problemas resultantes da fragmentação administrativa, de há muito vinham determinando a diretriz ora seguida. 


\section{O RITMO E OS PROCESSOS USADOS NA UNIFICAÇÃO}

A maior celeuma em tôrno da unificação é a que diz respeito, ainda, à forma por que as coisas começaram a ser feitas em alguns lugares. O ritmo demasiado acelerado e a falta de programações adequadas, por certo não concorreram para assegurar aos trabalhos uma receptividade maior no seio do pessoal.

Felizmente, êsses, são critérios fàcilmente mutáveis e adaptáveis às circunstâncias e a atual orientação administrativa, no particular, já se beneficia de um «modus faciendi» menos açodado e mais produtivo. Nem se conceberia, realmente, que a prazo demasiado curto se pudesse atingir, com plenitude, objetivo tão vasto e complexo, qual seja o de reunir sete entidades previdenciárias autônomas, muitas com problemática específica, num só órgão, de logo, plenamente atuante:

As limitações humanas, afinal de contas, são bastante fortes para interferir no processo de trabalho e ignorar-se isso, seria comprometer o êxito de qualquer empreendimento.

\section{PERDERAM, OS FUNCIONARIOS, COM A UNIFICAÇÃO?}

Evidentemente, nada perderam os funcionários com a unificação, pois os seus direitos e garantias fundamentais permanecem intactos, na nova organização.

Há, pelo contrário, uma inequivoca possibilidade de sua crescente valorização como grupo ocupacional, nas atuais circunstâncias. Ocorrendo, com efeito, como é de esperar-se, uma firme arregimentação dessa massa de noventa mil servidores, numa nova comunidade motivada pela identidade de interêsses e problemas, isso representaria, sem sombra de dúvida, a conquista da meta maior do seu robustecimento social e profissional. Um pressuposto necessário para o alcance dêsse alvo seria o estabelecimento de objetivos comunitários legítimos, que se caracterizariam, principalmente, pela feitura de oportunas reivindicações de interêsse da classe e pela defesa dos Institutos que já representam conquistas sociais e econômicas incorporadas ao seu patrimônio jurídico, sempre que em risco de serem supressas.

Como grupo de pressão, para usar a terminologia política corrente, uma comunidade assim numerosa e organizada dentro da lei e da ordem, teria, òbviamente, mais possibilidades de alcançar sucesso nessas lutas, do que greis fragmentárias, fàcilmente ligadas por liames tênues, como ocorria com as coletividades funcionais previdenciárias, anteriormente à unificação. 


\section{O «APPROACH» CORRETO DO PROBLEMA FUNCIONAL}

Voltando, porém, às nossas considerações iniciais, reiteramos entretanto que de nada valerão os planos e as programações, por mais técnicas e revolucionárias que sejam, se o comportamento do elemento humano que tiver de aplicá-los ou executá-las não fôr levado na devida conta pelo administrador. As causas naturais do descontentamento do funcionalismo e sobretudo a sua desinformação, a que já nos reportamos, e de que demos uma mostra em diferentes tópicos, devem, portanto, ser devidamente considerados pelos seus responsáveis, com vistas a neutralizar ou minimizar os seus efeitos negativos na tarefa de organizar e implantar o INPS. O êxito da unificação depende disso.

Não há fórmula miraculosa para o correto equacionamento do problema, mas um razoável trabalho de relações públicas, objetivando, especificamente, a clientela interna do INPS, seria um caminho natural no particular. O esclarecimento e preparo psicológico do servidor, no sentido de que receba a fusão com otimismo, constituem, assim, òbviamente, uma meta fundamental. Comporia, necessàriamente, êsse preparo, a divulgação das novas realidades da previdência unificada, em seus justos e reais valores, salientando-se, com especialidade, as perspectivas pósitivas do INPS, em cotejo com as fragilidades e deficiências da previdência social fragmentada.

Acrescentem-se, também, a essa programação, esclarecimentos sôbre as vantagens que adviriam aos servidores em particular, com a ampliação e generalização de concessões como a de uma assistência patronal eficiente, por exemplo. Promovam-se, ainda, e a curto prazo, a integração e reestruturação dos quadros, principalmente os de comando e supervisão, assegurando-se a manutenção de situações funcionais legitimas e necessárias e ter-se-á obviado um dos motivos mais fortes de apreensão do servidor, principalmente dos que ocupam postos de direção.

Palestras, cursos e publicações informativas seriam os instrumentos naturais dessa política, enfatizando-se a cooperação dos chefes, em particular, considerada a influência dos encargos de liderança que the são próprios, sôbre a coletividade funcional.

$O$ aproveitamento da experiência funcional comprovada, independentemente da anterior vinculação do servidor que a portar, a essa ou aquela entidade extinta é, também, fator básico de rápida integração administrativa do INPS. Ignorar-se essa circunstância seria alimentar um dos mais fortes motivos de desajuste das coletividades funcionais previdenciárias, ora, apenas, justapostas, mas ainda não verdadeiramente unidas. Plenamente cônscio dessa realidade está, aliás, o dr. Francis-
co Luiz Tôrres de Oliveira, como expressamente o salientou no 
seu discurso de investidura no cargo de presidente do INPS. Nessa oportunidade disse o nosso atual presidente que buscaria os seus auxiliares no campo de tôda a coletividade previdenciária, desde que inteirado das qualidades e aptidões dos seus integrantes, abstenção feita de sua origem administrativa. Nem poderia ser outro o procedimento de uma administração avisada e cônscia de que, para o equacionamento dos problemas específicos de muitas das antigas entidades, a experiência dos seus quadros no particular não poderia ser subestimada.

\section{CONCLUSÕES}

As conseqüências dessa politica não deixariam de traduzir-se na transformação paulatina da atitude do funcionário, que se tornaria num elemento preparado para enfrentar os fatos com realismo e construtividade, principalmente porque se dissipariam as suas suspeitas e frustrações. A sua integração numa nova comunidade funcional ampliada e sua receptividade às modificações dos processos de trabalho, seriam grandemente facilitados, pois todos reagem melhor aos problemas, aceitando-lhes as soluções, quando lhes sabem as origens. Por outro lado, um individuo convenientemente informado e esclarecido, mais fàcilmente se liberta dos preconceitos e «clichés» que lhe bloqueiam a mente, comprometendo-lhe a visão sensata das coisas. Reflexos positivos nos serviços do INPS não tardariam a se verificar, com ecos salutares no seio do público em geral, pois o que preocupa a coletividade não é pròpriamente que a Previdência seja administrada unificada ou fragmentàriamente, mas que os seus interêsses, junto à mesma, sejam atendidos com oportunidade, correção e eficiência.

Enfim, tudo se resumiria em saber conduzir o elemento humano e tirar dêle o melhor, pois como muito bem salientou Henry Fayol, já nos albores do século, numa visão de precursor e numa afirmativa a um tempo pragmática e humanista: «A administração», diz êle, «que comporta a aplicação de inúmeros conhecimentos e de muitas qualidades pessoais, é sobretudo a arte de lidar com homens».

\section{LEGISLAÇAOO CITADA}

Lei Orgânica da Previdência Social (Lei $\mathrm{n}^{\circ} 3.807$, de 26/8/60)

Lei da Reforma Administrativa (Decreto-lei $\mathrm{n}^{\circ} 200$, de 25/2/67)

Regulamento Geral da Previdência Social (Decreto $\mathrm{n}^{\circ} 60.501$ de 14 de março de 1967.

Lei Orgânica dos Serviços Sociais (Decreto-lei $n^{\circ} 7.526$. de 7/5/45). 


\section{NOMES CITADOS}

José Dias Corrêa Sobrinho

Frederick Winslow Taylor

Francisco Luiz Tôrres de Oliveira

Henry Fayol

\section{PUBLICAÇÕES CONSULTADAS}

\section{Previdência Social, de Celso Barroso Leite e Luiz Paranhos Veloso} Chambers's Encyclopaedia, verbêtes: Social Insurance e Ministry of
National Insurance

Administração Industrial e Geral de Henty Fayol do INPS

Mesário Estatistico Atuarial de maio de 1967 e Boletins de Serviço
INPS 